\title{
BRCA2 Gene Mutation Negative
}

National Cancer Institute

\section{Source}

National Cancer Institute. BRCA2 Gene Mutation Negative. NCI Thesaurus. Code C148085.

A genetic finding indicating that BRCA2 gene mutations have not been detected in a sample. 